\title{
Changes in the Economic Situation of the Transylvanian Catholic Community After the Trianon Treaty, with Special Regard to the Estates Managed by the "Erdélyi Katolikus Státus" (Transylvanian Catholic Státus) ${ }^{1}$
}

\section{Csaba Máté SARNYAI}

\author{
Művészettudományi és Szabadbölcsészeti Intézet, Bölcsészettudományi Kar, \\ Károli Gáspár Református Egyetem \\ Institute of Arts Studies and General Humanities, Faculty of Humanities, \\ Károli Gáspár University of the Reformed Church in Hungary, \\ Reviczky u. 4, 1088 Budapest, Hungary \\ sarnyai.csaba@gmail.com
}

The severity of the economic situation for the whole of the Catholic ecclesiastic assets and especially for the funds managed by the Status ${ }^{2}$ was not caused solely by the financial collapse and general impoverishment after the war, but also by the Romanian state's minority-, ecclesiastic- and asset politics.

One of the first laws to affect the Transylvanian Catholic Status and the whole of the Church economically was the 1921 agrarian act, created on the basis of the 1919 expropriation act. Octavian Goga, the politician of the Romanian Governing Council (Consiliul Dirigent) responsible for religious matters, already had made a statement on the issue in 1920, leaving little doubt about the fact that the law to be enacted, which served not only the purpose of solving economic problems, but also had a significant effect on internal politics: as an important tool for the "re-Romanian-isation" of Transylvania. ${ }^{3}$

According to the 6. clause of the act, "all rural and urban outskirts properties are wholly expropriated from all legal persons serving communal interests, such as: corporations, foundations, institutes, churches, abbeys, chapter-houses, universities, schools, hospitals, counties, villages, etc." ${ }^{4}$ From the 43,890 kh ('kataszteri hold' - a long outdated measurement unit of area, equals 0.57 hectares) estate of the Transylvanian episcopate; 6,333 $\mathrm{kh}$ remained theirs after the law came into effect; from the Oradea ${ }^{5}$ episcopate (partially annexed to Romania) estates, $37,556 \mathrm{kh}$; from that of Timişoara, ${ }^{6} 10,270$ and from that of

1 This research is supported by the National Scientific and Research Fund (Országos Tudományos és Kutatási Alap) (application number: PD 76004).

2 The strict definition in religious law is: "The Status is an organization of ecclesiastic and layman representatives elected by all Catholics in Transylvania, assisting the priests in the management of a part of the episcopate's wealth and in the management of the institutions that are funded by this wealth." Bertalan BAGOSSY et al, Az erdélyi katholicizmus multja és jelene, Dicsőszentmárton 1925, 376.

3 Péter SAS, Az erdélyi római katolikus egyház 1900-1948, Budapest 2008, 65.

4 lbidem.

5 In Hungarian known as Nagyvárad.

6 In Hungarian known as Temesvár. 
Szatmár ${ }^{7} 536$ kh came under state management. ${ }^{8}$

Due to the decision, the Status lost $88 \%$ of its estates. What's more, the significant handling fees and costs forced it to sell an additional $1 \%$ from its drastically diminished assets. Finally, $11 \%$ of the originally owned property remained in its possession. Usually there were no amends for the expropriated lands, or if there were, the price was rather low and instead of money, $5 \%$ interest rate state security bonds were offered to the diocese, ${ }^{9}$ which they did not even receive for years to come. Therefore, neither even these depreciating bonds could ever provide a real solution for the problems.

Meanwhile, they lost the money from the compulsory leases as well, previously paid by the Romanian farmers, to whom the Status was compelled to lease these lands. ${ }^{10}$

Thus the economic situation of the Status suffered a profound blow on the one hand, and even the maintenance of schools and other educational institutions was endangered on the other hand.

\section{Status lands expropriated through the 6 . clause of the 1921 agrarian act}

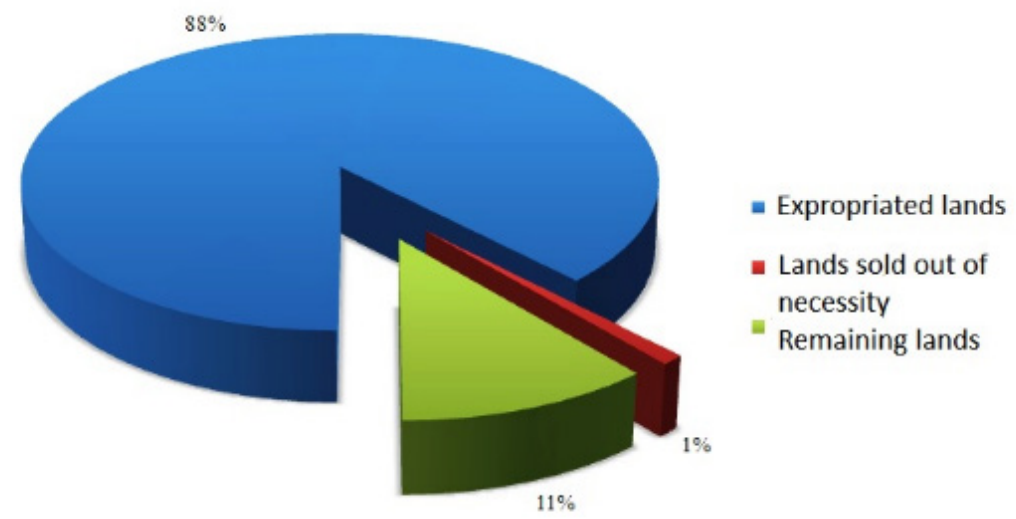

To understand the effects of the act on the other Hungarian denominations, we present summarised data on how (to what extent) the Romanian state expropriated lands from Catholics and Protestants: $314,331 \mathrm{kh}$ from an area of $371,756 \mathrm{kh}$, in other words: $84.5 \% .{ }^{11}$ Regarding the region of North Transylvania, the loss of non-Romanian denominations is $136,140 \mathrm{kh}$. From Romanian churches, the state expropriated 5,582 kh. It can be formulated that $96 \%$ of the total loss was suffered by non-Romanian churches and the two privileged religions lost to the state $4 \%$ of the their lands to the state (which used these lands for other purposes). ${ }^{12}$

\footnotetext{
7 In Hungarian known as Szatmárnémeti.

8 SAS, 66

9 lbidem.
}

10 Zoltán SZÖVÉRDY, Milyen az erdélyi agrárreform valóságban?, in: Magyar Szemle, 2, 1928, 4, 348.

11 János SCHEFFLER, Az “Erdélyi Katolikus Státus" küzdelmes húsz éve, in: Magyar Szemle, 40, $1941,5,300$.

12 Sándor BíRÓ, Kisebbségben és többségben. Románok és magyarok (1867-1940). Európai Protestáns Magyar Szabadegyetem, Bern 1989, 329. 
Due to the procedures of expropriation committees, Hungarian churches lost about $90 \%$ of their property and most of them were given over into Romanian management. ${ }^{13}$

The 4. paragraph of the 6 . clause decreed that every piece of parochial land was immune to expropriation up to the area of $40 \mathrm{kh}$. In addition, there were regulations to provide another $16 \mathrm{kh}$ for the upkeep of church schools. If the flock numbered more than 300, another $10 \mathrm{kh}$ was immune, making it a total of $66 \mathrm{kh}$. This $66 \mathrm{kh}$ was the minimum needed for the costs of maintaining schools and the church itself. The law gave guarantees in case the parochial property did not meet the required size. The deficit could be supplemented by state lands. In truth, however, this was put into practice only in the cases of the two 'privileged' churches. ${ }^{14}$

At the end of the war, Catholic parishes in Transylvania had 4,179 kh of land. They should have received $12,595 \mathrm{kh}$ to reach the legal minimum. Only three were given that, with an area of $21 \mathrm{kh}$ altogether. In fact, most estates were cut. At Baraolt, ${ }^{15} 47 \mathrm{kh}$ from 98, at Târgu Secuiesc, ${ }^{16} 76$ from 96, at Bezidu Nou, ${ }^{17} 45$ from 78. So the parishes in Ținutul Secuiesc ${ }^{18}$ did not even possess the legally guaranteed minimum, with the exception of the village Ojdula. ${ }^{19}$

The contrast between the state attitude toward Hungarian and Romanian churches was most prominent in Tinutul Secuiesc. ${ }^{20}$ While lands were taken from the religion of the Hungarians, now minority in the new state, these lands were given to the Romanians. The procedure served the long-term policy of the government, as they laid the financial foundations for the church of Romanians to be moved here later. These population movements served the purpose of changing ethnic conditions. The government intended to break the unity of Hungarians living in homogeneous blocks, as villages in Ținutul Secuiesc were populated by Romanians only sparsely at that time.

For example, the Eastern Catholic church possessed $10 \mathrm{kh}$ in Jigodin, ${ }^{21}$ though they numbered only 22. The church owned nine kh in Vrabia, ${ }^{22}$ but had no members there. They had five kh in Tuşnad-Sat, ${ }^{23}$ one in Păuleni, ${ }^{24} 30$ in lacobeni. ${ }^{25}$ Without one single believer,

13 After the passing of the law, the segmentation took place in a ceremonial manner, in some cases a member of the government was also present.

14 A possible source is the 1924 report of American mission in Romania, investigating the situation of Protestant churches, mentioning 43 cases where the decree was not applied to Hungarian churches. In its reflection, the Romanian government denied these. See: BÍRÓ, 1989, 329.

15 In Hungarian known as Barót.

16 In Hungarian known as Kézdivásárhely.

17 In Hungarian known as Bözödújfalu.

18 In Hungarian known as Székelyföld.

19 In Hungarian known as Ozsdola.

20 In Hungarian known as Székelyföld, in German known as Szeklerland.

21 In Hungarian known as Zsögöd.

22 In Hungarian known as Csíkverebes.

23 In Hungarian known as Nagytusnád.

24 In Hungarian known as Székelypálfalva.

25 In Hungarian known as Kászonjakabfalva. 
the Eastern Catholic church got ten kh at Mărcușa. ${ }^{26}$ The five-member parish of Ozun ${ }^{27}$ got ten kh for church upkeep from the Romanian government, and so did thirty Romanians in Sântionlunca. ${ }^{28}$ The same procedure was done in the case of the Orthodox church.

There was a singular case at Blaj, ${ }^{29}$ where the state expropriated 1,600 kh from the Eastern Catholic church.

The lawful compensations for the expropriations in the 1920 s never happened ${ }^{30}$ - there was a promise of state bonds in exchange for the lands, but contemporaries clearly agree that the depreciation of these bonds in the given economic situation would have rendered effective compensation for the loss impossible. The law would have provided a 5\%-worth bond worth 300-500 lei per each kh. ${ }^{31}$

Not only lands, but real estate was expropriated as well. In addition, individuals who had provided support so far were forced to part with their property in land and real estate. The memorandum to the Holy See claims about the situation of $48.8 \%$ of the Transylvanian Catholics that they became destitute, so the church lost their previous support as well. Until 1925, the Hungarian population in Transylvania lost 2,494,585 kh altogether, later amounting to $3,195,508 \mathrm{kh}$. The lands were given exclusively to Romanians. ${ }^{32}$

To manipulate public opinion, the press talked about a huge amount of resources and lands even in 1932, supposedly possessed and used by the organisation. In his speech to the Senate, Elemér Gyárfás refuted this claim, as these lands were given mainly by Báthori and, after the abolishment of the Jesuits, by Queen Maria Theresia, and their area had been diminishing as the centuries passed. The mentioned land reform also diminished their size. Gyárfás described an unproductive property of 220 million lei and he also emphasised that the upkeep of these is rather an additional burden for the Status and not a source of income. In his speech he claimed that only the two lent houses in Cluj-Napoca ${ }^{33}$ could count as a productive factor. ${ }^{34}$

There was a 1936 law that empowered the agrarian ministry (department) to give land back to its original owner, so in practice they were without the lands for some years and then the expropriations became void. Such a procedure never benefited Hungarian churches. 1936 also saw a so-called 'conversion act' on the compensation of the Romanian churches subjected to expropriations, another instance of discrimination as the law failed to regulate compensation to minorities. ${ }^{35}$

26 In Hungarian known as Kézdimárkosfalva.

27 In Hungarian known as Uzon.

28 In Hungarian known as Szentivánlaborfalva.

29 In Hungarian known as Balázsfalva.

30 András BALÁZS, Adatok az erdélyi kisebbségek iskolavédelmi küzdelmeihez. 1919-1929. Minerva irodalmi és nyomdai műintézet részvénytársaság, Cluj-Kolozsvár 1929, 221.

31 This means that the worth of the lands was calculated based on condtitons 5-10 years before, thus in the postwar conditions resulting in 5\% of its worth. See: Memorandum to the Holy See, 1921, 10.

32 lbidem.

33 In Hungarian known as Kolozsvár.

34 Minutes of the 1932. February 12 Senate session proves that Romanian senators used a highly cynical and mocking tone.

35 BíRÓ, 1989, 330-332. 
The 'racial intent' of the segmentation was already emphasised in the 1921 Memorandum of the Translyvanian Catholic laymen to the Holy See. According to the writers, their property would now cover the costs of the Eastern Orthodox and serve the emigration of Hungarians, thus changing the ethnic conditions and forcing the remaining population into a minority status, finally resulting in the extinction of the parish. ${ }^{36}$

British historian Seton-Watson (Scotus Viator, often referred to in the contemporary Romanian press), a facilitator of the Trianon peace treaty, also commented in a similar vein: ${ }^{37}$ "The agrarian reform not only bankrupted the Hungarian landowners, but, through the churches, the whole Hungarian intelligentsia as well, and sometimes it resembled an ethnic revenge." 38

For comparison, let us look at the 1911 "report on the 1910 activity of the Royal Govt. of Hungary and general conditions in the country". Its data show that between 1900 and 1910, 80,000 kh land in Transylvania was in Romanian possession. ${ }^{39}$ Sources in 1916 already mention a total of about 200,000 kh owned by the Romanian Greek Catholic church. ${ }^{40}$

Additionally, Romanian schools received 1,300,000 crown financial support from the government, though there was no state-language education in most of them. ${ }^{41}$

After 1918, not only the expropriation of estates meant a loss for the church, but also the fact that it was cut off from significant income sources from the Hungarian state. ${ }^{42}$ The Romanian state was discriminative of churches and ethnicities in the case of the kongrua, a sum to complement clerical wages as well. Its granting began in 1920; for about 10 years there were no such flagrant discriminations noted like those during the agrarian reform; the distribution went more or less according to the regulations. But in 1931, minister Costãchescu drafted a change to grant the kongrua in proportion of the number of believers. It must be noted that this was against the 31. clause of the relevant cultural law that dictated the consideration of financial conditions and demands of the churches as well.

The kongrua of Catholic priests was between 2050 and 3000 lei after 1931, calculated from the number of followers. There was a further decrease of income in the following years. By 1933, Catholic priests had received 4,606,209 lei less state support altogether. ${ }^{43}$

The economical report for the 1935 congress of the reformed church also attests to the same: "Though it increased somewhat in its absolute total, the kongrua of our pastors do not reach the subsistence wage, and was even decreased, especially at urban places, to a couple of hundred lei. The equalisation with the kongrua of majority churches failed, despite all our efforts. [...] Parallel to the decrease of the kongrua, our parishes are further

36 Memorandum to the Holy See, 1921, 11.

37 Robert William Seton-Watson (1879-1951), Scotus Viator was his early pseudonym. See: Géza JESZENSZKY, Seton-Watson és a magyarellenesség, in: História, 9, 1987, 1, 36; his activity was truly controversial in the $20^{\text {th }}$ century on both sides of the new Hungarian borders as he was a major agent and later defender of the Trianon treaties.

38 SAS, 67.

39 Ignácz KOSUTÁNY, A római katholikus egyház Erdélyben, Cluj 1924, 8.

40 BÍRÓ, 1989, 329.

41 KOSUTÁNY, 8.

42 SAS, 65.

43 BÍRÓ, 1989, 332-333. 
punished by the ministerial decision that if a pastor's position becomes vacant due to death, retirement or resignation, the kongrua is cancelled for the fiscal year, and the newly elected pastor receives kongrua only if he brings it from another kongrua-worthy position, in which case the other church will be without kongrua. Newly graduated curate pastors could not be appointed to any position with kongrua. Appeals and personal interventions in this matter have remained ineffective to this day. If this regulation is to stay for longer, in a few years we will have to consider the possibility of the kongrua taken away from our pastors." 44 Though the above quotation has a Protestant source, the situation of Catholic clergymen was not much different.

It should not be forgotten that granting or withholding the state kongrua was an excellent tool of coercion for the state, a suitable negotiating position to 'regulate' 'rebel' priests, pastors and church principals, as it could be denied any time to any clergyman who failed to serve the central interests and ideology. This was done several times, especially after 1934. It was enough if one abstained from state celebration events, and in most of the cases speaking or acting against the state, or 'irredenta' behaviour was the justification. The cultural minister could make such a decree any time, there was no need for any official investigation.

Apart from this, the state disposed of the salary of theology teachers and central religious leaders as well, possessing similar options in their cases, too. ${ }^{45}$

\section{The Legal Debate on the Expropriations}

As it can be seen, the former property of the Catholic Status of Transylvania and the related management rights were claimed by Romania just after Transylvania was annexed to the country. The Status' rights to the religious and educational funds, real estates and other property were legally questioned. The primary argument was that all rights that the Hungarian state had exercised in Transylvania were transferred onto the Romanian king, thus onto the state.

In the following section we discuss the legal recognitions and church law foundations that the Status had in this regard.

A major function of the Status is monetary management, namely that of educational funds and the maintenance of denominational schools. Members of this institution of the Transylvanian Roman Catholic community strived to prove and justify their rights by citing historical facts, with special regard to the last fifty years of the organisation's history.

Just like the Status itself, those funds that made up the church's communal wealth, came to be through historical processes. These are the followings: religious funds, ${ }^{46}$ educational

44 BÍRÓ, 1989, 333.

45 BíRÓ, 1989, 333-334.

46 The fund (Cassa Parochorum) was created by Charles VI in 1733, to support parochial priests. After the 1773 abolishment of the Jesuits, Maria Theresia unified it with the Fundus Lusitanicus, a Portuguese Jesuit Mission fund. Then in 1782, Joseph II merged the wealth of abolished monastic orders and monasteries and the so-called castle-building contribution of high priest into the fund. In the same year, ecclesiastic wealth and incomes were also placed under the superintendence of this fund. 
funds,${ }^{47}$ tuition funds,${ }^{48}$ Theresa orphan funds,${ }^{49}$ elementary school funds,${ }^{50}$ pension funds, ${ }^{51}$ insurance funds. ${ }^{52}$ Among these, the insurance and the elementary school funds are not included directly in the rulings of the 9 February 1868 Status congress. But they are mentioned indirectly, as the rulings list the funds for teacher salaries..$^{53}$ The same costs appear in the 13 May 1931 rulings, directly under their respective funds. ${ }^{54}$

According to the 1581 foundational document, Transylvanian prince István Báthori gave the dominium of Cluj-Mănăștur ${ }^{55}$ (previously the property of the Benedictine order) to the Jesuits, as a Catholic foundation. His purpose was to "propagate Catholic interests", within and outside schools. ${ }^{56}$ After the Jesuits had been banished by Protestant monarchs, part of the estates went to the treasury first, and then to private individuals. Leopold I made an agreement with the Transylvanians and allowed them in his April 1693 edict to buy back the estates, so they became property of the church, for the upkeep of churches and schools, with "eternal property rights". In 1732 they managed to reclaim the remaining part of the lands, by the 15 October edict of Charles III. But it was done through their own money and without compensations, so raising of the sum cost them much. By the 1744/8. article the dominium was erased from the pura fiscalitas. ${ }^{57}$ This is how it became, finally, the basic estate of the Status' educational funds after the 1773 abolishment of the Jesuits, with the consent of the monarch. The legal foundation for this was the 'ius supremi patronatus' of the apostolic King, the right that granted Hungarian kings the superintendant rights over Catholic wealth. ${ }^{58}$

The synod of Trident sanctified the standpoint that the foremost manager of the Catholic Church's material wealth is the Pope. It is not part of any nation's, state's or ruler's property, not even to the extent of supervision rights. Such rights belong to the bishop of the episcopate. "As the years passed, however, the Church granted certain honorary rights to laymen who distinguished themselves through saving or donating to ecclesiastic wealth. (...) It was only by the Church's license and privilege that Hungarian kings could receive the rights that they had exercised historically since St. Stephen." 59 These feudal rights applied only to those estates that the kings themselves donated, and not to those donated by private individuals.

This right widened ever more as time passed. During the expansion of the Reformation,

47 Created by Maria Theresia in 1782 from the former wealth of the Jesuits.

48 Similar to the education funds in every regard.

49 Orphanage in Sibiu, 1770.

50 1776, Maria Theresia.

51 Pensions for elementary school teachers, gymnasium teachers and Status clerks.

52 Not really of the Status, rather of its members.

53 From the archives of the Status.

54 C.f the 1931 Operational Regulations of the Status.

55 In Hungarian known as Kolozsmonostor.

56 BAGOSSY, 359.

57 Chancellery wealth.

58 BAGOSSY, 360.

59 lbidem, 378. 
the church asked the kings for help in defending the faith. They perpetrated actions that only the relevant ecclesiastic personalities had rights to. This is when a new practice was adopted: that the management of "vacated ecclesiastic wealth" was appointed to the royal chancellery. ${ }^{60}$

All of these factors were important in the eventual extension of the 'ius supremi patronatus'. Thus it meant (among other things) the supervision over ecclesiastic wealth and the right to its overwatch. ${ }^{61}$ The right, originally an "honorary right recognised by the Pope" 62 entered the legislation, thus becoming common law. It was among regal rights, but the 'ius supremi patronatus' does not equal the personal regal rights of the king. ${ }^{63}$ Maria Theresia and Joseph II overused these licenses that were not really rightfully theirs in that particular form. ${ }^{64}$ "By Hungarian constitutional law, the Hungarian king becomes heir to St. Stephen through the Holy Crown. At the coronation, which takes place during a Holy Mass, the king swears an oath to protect the rights of the Catholic Church. In turn, the archbishop of Esztergom crowns him with St. Stephen's crown and this is what grants him the 'supremi patronatus' rights." 65 As the land of the country belongs to the Holy Crown, and the king is not the sole possessor of the rights of the Holy Crown, the lands are not part of his own private property. As the "person to exercise communal power", he has got donation rights, ${ }^{66}$ but it derives from the above notions that it is not a private right, as he does not donate from his own property. "Therefore, the royal donation does not constitute a relation of private law between the donating king and the recipient."

These are significant circumstances, because if the 'ius supremi patronatus' of the king had derived from his general regal rights, then the same right over Hungary's every taken territory would be transferred to the claiming states. Now, though the Romanian government does act as if this was the case, ${ }^{67}$ but there is no historical precedent for such a legal transference. This right was suspended during the era of Transylvanian princes ${ }^{68}$ and the descendant states are not automatically granted with it, and in fact, neither is the Hungarian governor. 69

Onisifor Ghibu also claims that the right of the Holy Crown was transferred onto Romania. Opposing this, Kosutány states that "it never transferred to the Turkish sultans, neither to the Roman emperors, even to I. Franz Joseph only when the country crowned him king in 1867. 'And it does not transfer to Romania either'."70

It is worth mentioning that the partiality of the 'ius supremi patronatus' points out the differ-

$60 \mathrm{lbidem}, 379$.

$61 \mathrm{lbidem}, 380$.

62 Ibidem, 382.

63 Ibidem, 380, 382.

64 János KARÁCSONYI, Ne faljuk fel egymást, in: Magyar Kisebbség, 3, 1924, 7, 298.

65 BAGOSSY, 381.

66 KOSUTÁNY, 14.

67 László FRITZ, Ghibu Onişifor: Egy anakronizmus és egy kihívás II., in: Magyar Kisebbség, 11, 1932, 5, 145.

68 BAGOSSY, 384.

69 Ibidem, 381.

70 KOSUTÁNY, 14-15. 
ence of canonical law between the Status and the Catholica Commissio. In medieval times, kings exercised these rights by the mediation of court personnel.

The Commissio had a similar role, managing issues that were supremi patronus, but this did not interfere with the existence of the Status and neither with its rights to address issues that fall under ecclesiastic competence. The Commissio was an "internal affair" of the king as supreme feudal patron. ${ }^{71}$

The superintendence rights of the Catholic church's material wealth is possessed by the bishops in the dioceses. ${ }^{72}$ Thus the Status was often accused of being a "Protestant-ish group that vindicates episcopal rights to itself and restricts the bishop's power down to the narrow licences of Protestant high pastors. "73 So its abolishment won't harm Romania's relations neither with the Alliance of Nations nor with the Holy See, as it "restores forever the everywhere usual canonical legal situation of the universal Catholic church in the R. Cath. Episcopate of Alba lulia as well, unlike the legal situation created by the $18^{\text {th }}$ century Austrian government and continued by the $19^{\text {th }}$ century Hungarian government. ${ }^{174}$

But the legal competences of the Catholic bishops are not restricted to managing the wealth of the diocese or to the superintendence of schools, so these accusations are clearly exaggerated. As we have seen, the aristocracy had not much other choice but to take over the management, but since the bishops returned to Transylvania, they have lead the Status and shared these rights with it, not forfeiting them. While the Protestant high pastors are subordinated to the assemblies in their pastoral districts, bishops in Transylvania preside over the Status assemblies. And ecclesiastic law does not prohibit this form of monetary management, either. According to the 1519. and 1520. canons of the Codex luris Canonici, it is the bishop's task to manage the money. He shall set up a management committee of at least two members at his resident town, unless "a special law or custom have already provided a lawful mode of management." 75 Of course, these canons refer to the superintendence of the wealth, but the Status also manages them. It can do so according to the 2. paragraph of the 1521. canon allowing the participation of laymen in such activities provided that the bishop consents and his supervision rights are undisturbed. Another condition is the consent of the founders, ${ }^{76}$ which has, as we have seen, been granted by the Status' recognition. Therefore, all conditions were given for the Status to fulfil the role of superintending the educational institutions, to define their operational framework and manage the funds that sustain them.

The ministerial order No. 896 (12 September 1867) could be cited as a basis of reference, according to which the Catholica Commissio is done away with and its place and responsibilities are taken over by the "Erdélyi Katholikus Státus". A temporary committee took the functions of the Commissio until 1873, it exercised the rights and organised the takeover

\footnotetext{
71 Ibidem, 386.
}

72 lbidem, 378

73 Ibidem.

74 László FRITZ, Ghibu Onişifor: Egy anakronizmus és egy kihívás I., in: Magyar Kisebbség, 11, 1932, 3-4, 109.

75 BAGOSSY, 389.

76 Ibidem, 390. 
that was finished in 1873. In the common law, this is the basis of the Status' existence. ${ }^{77}$ The years after the union with Transylvania were regarded as a temporary situation. Some thought it less than desirable if the ministry managed religious and educational funds until the formation of country-wide autonomy. The Status also initiated the realisation of this. Supporters would have liked the wealth to be managed by either the Erdélyi Katholikus Status or the national autonomy.

Though cultural minister Ágoston Trefort did not let the Transylvanian funds leave state-management in 1873, contemporary sources report that the Status used them and participated in their actual management. ${ }^{78}$

The reasoning from the members was that the minister did not wish the transition to interfere with the future issues of the forming autonomy, and that task distribution and its relation to the Transylvanian organisation was not yet perceivable at the time. ${ }^{79}$ Ferenc Csorba emphasises that practically only petitions came to the ministry, and from there they only expected agreement. The right to the funds and their management belongs to the Religious and Educational Ministry, as it takes part in the management as the executive of the ius supremi patronus. The Status could not receive these at this time, because these are national foundations and their autonomy is only diocesan and not country-wide. ${ }^{80}$

The rights to wealth management were granted by international treaties as well, ${ }^{81}$ but after Transylvania went under Romanian authority, exercising of these rights was seriously obstructed.

Oanea's opinion, which he also stated in the Romanian Senate, was that in 1873 the Catholic Status just simply claimed this part of the state property, basically arguing that it was stolen. ${ }^{82}$

After the imperial change, the Status referred to the fact that the Hungarian state cannot have any claims to the wealth, as the given territory doesn't belong there anymore, so its management is their task and right. The Romanian standpoint about their "inheritance" of rights was a reaction to this.

\section{Summary}

Romania's estate politics after the Trianon treaty caused about 24,207,138 lei deficit in the school and religious funds managed by the Status. Compared to the incomes of years before 1920, the religious fund suffered a deficit of 2,542,659 lei, the educational fund's deficit was $8,480,086$ lei, the elementary school funds' $13,619,274$ lei. Only the pension

\section{BALÁZS, 219.}

78 For example the purchase of the Almașu Mare (in Hungarian known as Nagyalmás) and lernut (in Hungarian known as Radnót) dominiums.

79 Az erdélyi római katholikus status: Emlékirat, melyet az erdélyi róm[ai] kath[olikus] Státus igazgatótanácsa Románia kormányához román nyelven terjesztett fel 1932. január 20-án, Cluj-Kolozsvár 1932, 9.

80 Ferencz CSORBA, Obstructió és cloture, Budapest 1891, 26.

81 BAGOSSY, 333.

$82 \mathrm{Az}$ erdélyi katholikus státus a szenátus előtt: Gyárfás Elemér világi elnök beszéde és N. Jorga minister elnök válasza a Szenátus 1932. február 12. ülésén (Különnyomat az Erdélyi Tudósító 5. számából) 1932, 8. 
funds of clerks and teachers gained some additional profit. ${ }^{83}$

In other words, the expropriation of Status estates meant a very serious loss. Their income was spent on the larger part of the costs of the institutions that they operated. It is understandable that such a dramatic loss of income had serious consequences. Only $11 \%$ of ecclesiastic lands remained. ${ }^{84}$ The greatest difference between incomes and expenses was in the cases of the educational fund and the elementary school funds. So education was the most affected field, just as intended by the creators of the edict. The number of denominational schools decreased due to source redistributions and other obstructive decisions, and even the maintenance of the remainder was possible only through the selflessness of the followers. ${ }^{85}$

But it must be noted, as the above analysis shows, that an exact explanation for such a situation, according to present expectations, cannot be given today. The common origin of the particular issue and the related problems is the monetary property rights of the church. ${ }^{86}$ The clergy's standpoint is, in this regard, basically unchanged. According to them, this is private property, the legal nature of which is completely similar to that of the aristocratic estates, with regard to acquisition and possession as well. So it is received either as donation for achievements or by way of accession and is possessed in a way that is both eternal and inalienable. Churches and noblemen are holders of the very same privileges.

A liberal reasoning appeared in the 'reform age' of Hungarian history (and was continued in the age of dualism), arguing that the clergy was a faculty of state clerks for cultural and religious issues, as far as the property rights of ecclesiastic wealth are concerned. The state clerk got his salary for the fulfilling of certain functions appointed by the state, but in that era it was not money, but donated estates. The goal of the liberals is the separation of church and state. In the de-sacralised state, churches were understood as a private association of identical beliefs. Thus their clerks are no longer entitled to use the wealth received as their salary after their functions were taken over by the state. This train of thought refutes the accusation of property right violation, arguing that ecclesiastic property was never owned by the church, the church only possessed it. The owner was and is the state. Therefore, there is no valid claim of compensation for it either.

They also strived to support the justification of the above ideas historically. In their retrospection, the facts of feudal law history were interpreted through principles of civil law.

The difference between clerical and liberal views is rooted in the essential difference between the feudal and modern civil concepts of property. From the feudal perspective, the actual possession is relevant, which has a 'legally binding, law-generating' effect. This is how the temporary beneficium could become an inheritable feudum. In addition, the 'ius fiscalitatis' (the property rights of an estate returning back to the state in the case that the possessor dies without heirs) did not even apply to the church, because it could be only the

83 SAS, 67.

$84 \mathrm{lbidem}$.

85 István SULYOK, Végső veszedelemben középfoku oktatásunk III., in: Magyar Kisebbség, 2, 1923, 13, 496-497; Sándor BÍRÓ, Az erdélyi magyar iskola keresztútja, in: Magyar Szemle, 40, 1941, 1, 27-35, 31.

86 In our analysis we mainly used the following articles: László CSORBA, A szekularizáció kérdése a reformkori országgyúléseken, in: Világosság, 1979, 603-610; László CSORBA, A vallás alap jogi természete, Budapest 1999 , $29-44$. 
recipient ecclesiastic person losing the donation, the donation itself still remaining in the hands of the church. The civil concept of property is focused otherwise. Liberal reformers considered the nation, exercising 'ius disponendi' through its legislation, to be the real owner of ecclesiastic wealth. Based on this, they could interpret that an estate (received in feudal donation) is actually a payment and cost-compensation toward the church as a state office, and is still disposed over by the nation.

The latter argumentation is reinterpreted by the contemporary lgnác Kosutány: "the property and the property rights of the Hungarian Catholic ecclesiastic wealth is 'incompatible with the categories of our modern legal concepts and mindset' (...) It differs greatly from everything that the modern jurist recognises as property, property right and estate. (...) The legal concept of the 'Hungarian ecclesiastic wealth cannot be construed' according to our concepts today. It is the remnant of a past and gone age, when those factors that are basic factors of the legal system today (...) did not exist or were yet underdeveloped. Then again, there were such (...) that no longer exists today. (...) Hungarian ecclesiastic wealth belongs and belonged to private law only partially, and its larger part belongs to Hungarian state law. And private and state law are in such a relation with each other as (...) making any modern definition impossible. This is why the subject of the property law of the Hungarian ecclesiastic wealth 'cannot be defined by today's legal mindset'. The concept of ecclesiastic wealth is a historical concept" 87 All of this should be kept in mind. The primary goal of those who worked much on the elimination and abolishment of the Status was to acquire the money of these funds. For this purpose, they attempted to confuse the legal interpretation of the time when the Status and the funds were created with the interpretation of their own time. Such a confusion attempt is actually "an abuse of scholarship", its "violation" and an opportunity for false explanations. ${ }^{88}$

\section{Incomes and demands of Status funds after the expropriations}

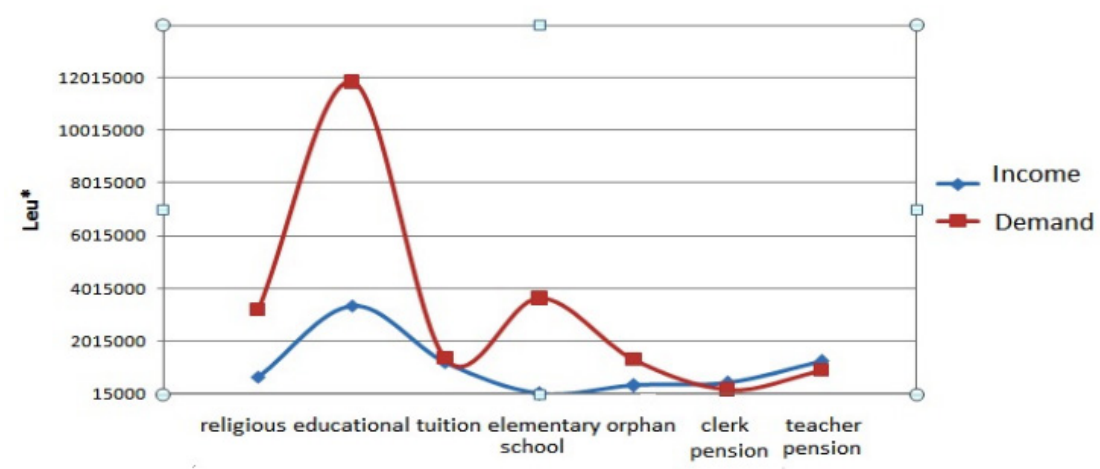

Incomes and demands of status funds after the expropriations, from left to right: religious, educational, tuition, elementary school, Theresa Orphanage at Nagyszeben, cleck pensions, teacher pensions. 


\begin{abstract}
Romania's estate politics after the Trianon treaty caused about 24,207,138 lei deficit in the school and religious funds managed by the Transylvanian Catholic Status. It is understandable that such a dramatic loss of income had serious consequences. Education was the most affected field, just as intended by the creators of the edict. The number of denominational schools decreased due to source redistributions and other obstructive decisions, and even the maintenance of the remainder was possible only through the selflessness of the followers.

But it must be noted, as our analysis shows, that an exact explanation for such a situation, according to present expectations, cannot be given today. The difference between clerical and liberal views is rooted in the essential difference between the feudal and modern civil concepts of property. The primary goal of those who worked much on the elimination and abolishment of the Status was to acquire the money of these funds. For this purpose, they attempted to confuse the legal interpretation of the time when the Status and the funds were created with the interpretation of their own time. Such a confusion attempt is actually "an abuse of scholarship", its "violation" and an opportunity for false explanations.
\end{abstract}

\title{
Keywords
}

Religious freedom, ethnic minorities, concordats and minorities

\section{References}

Az erdélyi katholikus státus a szenátus előtt: Gyárfás Elemér világi elnök beszéde és N. Jorga miniszterelnök válasza a Szenátus 1932. február 12. ülésén (Különnyomat az Erdélyi Tudósító 5. számából) 1932, 8.

Az erdélyi római katholikus státus: Emlékirat, melyet az erdélyi róm[ai] kath[olikus] Státus igazgatótanácsa Románia kormányához román nyelven terjesztett fel 1932. január 20-án, Cluj-Kolozsvár 1932, 9.

BAGOSSY, Bertalan et al: Az erdélyi katholicizmus multja és jelene, Dicsőszentmárton 1925. BALÁZS, András: Adatok az erdélyi kisebbségek iskolavédelmi küzdelmeihez. 1919-1929. Minerva irodalmi és nyomdai műintézet részvénytársaság, Cluj-Kolozsvár 1929.

BÍRÓ, Sándor: Az erdélyi magyar iskola keresztútja, in: Magyar Szemle, 40, 1941, 1, 27-35. BÍRÓ, Sándor: Kisebbségben és többségben. Románok és magyarok (1867-1940). Európai Protestáns Magyar Szabadegyetem, Bern 1989.

CSORBA, Ferencz: Obstructió és cloture, Budapest 1891.

CSORBA, László: A szekularizáció kérdése a reformkori országgyűléseken, in: Világosság, 1979, 603-610.

CSORBA, László: A vallás alap jogi természete, Budapest 1999.

FRITZ, László: Ghibu Onişifor: Egy anakronizmus és egy kihívás I., in: Magyar Kisebbség, 11, 1932, 3-4, 106-116.

FRITZ, László: Ghibu Onişifor: Egy anakronizmus és egy kihívás II., in: Magyar Kisebbség, $11,1932,5,144-150$. 
JESZENSZKY, Géza: Seton-Watson és a magyarellenesség, in: História, 9, 1987, 1, 36.

KARÁCSONYI, János: Ne faljuk fel egymást, in: Magyar Kisebbség, 3, 1924, 7, 296-302.

KOSUTÁNY, Ignácz: A római katholikus egyház Erdélyben, Cluj 1924.

SAS, Péter: Az erdélyi római katolikus egyház 1900-1948, Budapest 2008.

SCHEFFLER, János: Az "Erdélyi Katolikus Státus" küzdelmes húsz éve, in: Magyar Szemle, 40, 1941, 5, 299-310.

SULYOK, István: Végső veszedelemben középfoku oktatásunk III., in: Magyar Kisebbség, 2, 1923, 13, 496-497.

SZÖVÉRDY, Zoltán: Milyen az erdélyi agrárreform valóságban?, in: Magyar Szemle, 2, 1928, 4, 345-348. 